\title{
SUBJETIVISMO, IDEALISMO, ARQUITETURA UMA VISÃO ECOPOLÍTICA E PROSPECTIVA
}

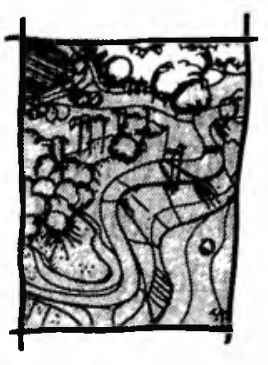

SAIDE KAHTOUNI

A questão básica da discussão que nos propomos iniciaréa seguinte: em nossas mãos está o poder de projetar algo que será real, mas que surge de um juízo.

Arquitetos e urbanistas são agentes da ação humana sobre seu suporte físico natural ou já artificializado. Essa ação pode ser considerada um meio de conhecimento, à medida em que ocorrem interações e trocas entre um sujeito (no caso, $o$ agente), e um objeto (o ambiente).

Hessen, no seu estudo "Teoria do Conhecimento" datado de 1926, apresenta a observação de diversas correntes filosóficas e a sua classificação de acordo com a valorização ora do sujeito, ora do objeto, como origem e essência do conhecimento, levando-nos a concluir que no decorrer da história da epistemologia formaram-se originalmente dois grandes blocos básicos, antagônicos que, se no início estavam simetricamente opostos, em posturas extremas e radicais, tendem a se aproximar lentamente através do estabelecimento de posturas mediadoras.

O primeiro bloco está nitidamente vinculado ao mundo da matemática e da geometria, valorizando a razão, os processos mentais e subjetivos como meio, origem e essência de conhecimento e é representado por correntes como o Idealismo, o Subjetivismo, o Racionalismo. Osegundo grandeblocoestá vinculado aodesenvolvimentodasciências físicas e naturais, alicerçado na observação, na medição, na descrição de fenômenos e objetos, representado pelas correntes realistas, objetivas, empíricas e outras.

Na verdade, toda a busca da filosofia ocidental contemporânea reside na busca de um ponto intermédio ou interativo entre os dois extremos: sujeito e objeto. Kant é o grande iniciador dessa procura, através de pensamentos que superam tanto uma ou outra postura radical, colocando-se sempre como fator de integração de pontos de vista de uma ou outra.

De maneira praticamente análoga, o estruturalismo já conseguiu superar a antiga discussão epistemológica da definição de todo. É clara, no raciocínio estruturalista a interação dinâmica entre a parte e o todo. Segundo Piaget, a definição de totalidade através das estruturas operatórias adota desde o início uma atitude relacional, "o que não conta não é nem o elemento, nem o todo se impondo como tal, sem que se possa precisar como e sim as relações entre os elementos ou, em outras palavras, os 
procedimentos ou processos de composição (segundo se fale de operações intencionais ou de realidades objetivas), não sendo o todo senão a resultante dessas relações ou composições, cujas leis são as do sistema"

Aplicando o raciocínio estruturalista à dicotomia sujeito/objeto, poderemos compreender melhor as relaçõese os processos entre um e outro sob o ponto de vista "ecopolítico"

Um raciocínio do próprio Kant diz que, contrastando com a existência de um pensar, existe o caos. No entanto, o que é o caos? é simplesmente o que não se conhece, o que não é dominado pelo pensamento. Durante muito tempo, e ainda hoje, o suporte de nossas ações ainda é assim considerado; muitas pessoas não podem ou não querem admitir que o que está fora de suas consciências tem uma estrutura própria, uma lógica, uma ordem, que é apenas desconhecida.

Emuitas vezes somos obrigados a intervir sobre esse "caos", na qualidade de arquitetos, organizadores físicos. Na verdade não estamos criando uma nova realidade sobre 0 caos, mas estamos agindo sobre sistemas que reagem às nossas decisões técnicas.

Se, por um lado, as tendências de caráter objetivista levaram a um determinismo exacerbado, a um sentimento extremo preservacionista, a uma atilude exageradamente descritiva e fetichista, culminando na inação de classes técnicas que teriam dentro de suas funções o poder transformador; por outro lado as posturas idealistas, subjetivistas e afins tendem a fazer uma redução da realidade tanto no sentido modelístico, quanto hierárquico - valorizando o lado mental da experiência de projeto.

Vem daí a intensa e extensa desconexão entre intervenções e suportes, que tendem a não levar em conta especificidades físicas ou mesmo sócioculturais. Os modelos, os arquétipos, as tipologias homogeneizados se difundem, caracterizando a Relação de Ruptura entre o homem e o seu próprio sistema, contrária a toda a busca da postura estruturalista.

Evisãoecopolítica, emergente nas últimas décadasédifundida por pensadores das mais diversas áreas do conhecimento no mundo inteiro, procurando compreender e analisar a crise mundial que hoje se atravessa, reafirma os estruturalismo na medida em que considera o homem como um dos elementos de um sistema complexo que envolve relações sóciopolíticas e relações ecológicasdomeioambiente físico. Eainda ultrapassa as questões colocadas pelos esıruturalisıas quando trata não só de populações humanas, mas das relaçōes entre as intervenções humanas e outras populações vegetais e animais.

É importante dizer aqui que a visão ecopolítica difere bastante da visão determinista vinculada às Ciências Naturais e restritamente biológica, à medida em que leva em 
conta a capacidade de escolha dos homens e a razão do indivíduo, essência de sua capacidade de transformação do meio ambiente.

Nesse sentido, transcende oexistencialismo justamente por tratar de escolhas coletivas, de uma sociedade política, suscitadas pela complexificação sistêmica e das organizações, pela evolução política, pelo aumento da capacidade de destruição humana através da majoração dos impactos das decisões técnicas e pelos níveis de comunicação sempre crescentes, além da busca da espiritualidade das ações e dos produtos da transformação humana.

No início desse século Eisler disse: "a objetividade reside na possibilidade de um conhecimento universalmente válido para vários sujeitos"

"Os movimentos ecológicos e pacifistas constiluem-se num ponto de inflexão na história da mobilização social e da ação coletiva; trata-se de movimentos portadores de valores e interesses universais que ultrapassam as fronteiras de classe, sexo, raça e idade... Sua base social atravessa definidamente as fronteiras de classe (participam profissionais de alta qualificação, estudantes, camponeses, colarinhos brancos, funcionários públicos, operários, pequenos empresários, executivos); sexo (participam homens e mulheres); raça (há participaçāo de minorias étnicas); idade (desde jovens esludantes e crianças do primário até aposentados). O movimento ecopacifista tem o potencial de incorporação da grande maioria da humanidade (a paz e o equilíbrio ecológico estão diretamente associados à própria sobrevivência da espécie; exceto somente os agentes sociais que ocupam as posiçōes dominantes do complexo militarindustrial científico da maioria dos países, que são intrinsecamente portadores da lógica predatório-exterminista contemporânea." (Viola, 86)

Podemos então compreender o quanto a visão de vida humana, que o movimento ecopolítico nos traz, significa um ponto de inflexão ou ruptura - na história do pensamento e do senso comum no Ocidente, constituindo-se em novo paradigma, que encontra suas origens nos movimentos socialistas do séc. XIX e os transcende, para um significado universal.

Michel Laurie, em seu livro Arquitctura da Paisagem, cita Gutkind, que na década de 50 dividiu a relação homem/suporte em quatro momentos universais. O primeiro, de temor em relação à natureza, vinculado aos modos de vida das tribos primitivas; o segundo, onde a consciência dos ciclos naturais proporcionou a adaptação humana, sob formas lentas de transformação social e cultural, ligada às civilizações orientais; a terceira dominante no presente seria a da conquista e da agressão, onde o domínio de tecnologias ressalta a hegemonia do homem e ao mesmo tempo ocasiona desastres; e 
a quarta e última, ainda em desenvolvimento para o futuro, baseada na compreensão do "caos", que deixa de ser o "caos" e passa a ser tratado com responsabilidade, em busca da unidade (outra vez o ponto interativo!).

Ao arquiteto cabe uma parcela das decisões sobre as soluções para as transformações espaciais. As opções que se apresentam podem ser unificadoras, integradoras ou desintegradoras (hoje dominantes). Mais do que uma questão partidária, essas escolhas estão vinculadas a uma postura filosófica, ou mesmo política, em seu sentido mais essencial.

As questões que se colocam para a prospeç̧ão residem na busca dos métodos para se encontrar soluções integradoras na arquitetura e urbanismo; e na compreensão das relações entre a ecologia, a cidadania, as estruturas sociais, a avaliação das ações humanas como fonte de conhecimento e reflexão, o progresso, no senlido de evolução sistêmica.

Voltemos então ao nosso problema básico. "Em nossas mãos está o poder de projetar algo que será real, mas que parte de um juízo." Essa é nossa responsabilidade política.

\section{BIBLIOGRAFIA}

Hossen, Johannes Teoria do Conhecimento. $7^{73}$ Edição, Armênio Amado Editora, Portugal, 1980.

Immanuel, Kant Prolegômenos a toda Metafísica Futura. Edições 70, Lisboa, 1982.

Laurie, Michal Introducción a la arquitectura del paisaje. GG, Barcelona, 1983.

Piaget, Jean O Estruturalismo. Ed. Difel, 2-a edição, São Paulo, 1974.

Viola, J. Eduardo O movimento Ecológico no Brasil ( 1974 1986): do ambientalismo à ecopolítica. Universidade Federal de Santa Catarina, Mimeo, 1986. 